\title{
The Relationship between Democracy and Economic Growth in Tunisia: An Application of Autoregressive Distributed Lag Model
}

\author{
Lamia Arfaoui \\ Doctor in economics, Member of PS2D Research Unit \\ El Manar University, Tunisia \\ Azza Ziadi (Corresponding author) \\ Doctor in economics, Member of PS2D Research Unit \\ El Manar University, Tunisia \\ E-mail: ziadiazza@yahoo.ca \\ Sonia Manai \\ Doctor in economics, Member of PS2D Research Unit \\ El Manar University, Tunisia
}

Received: January 15, 2016 Accepted: February 17, 2016 Published: March 7, 2016

doi:10.5296/ijssr.v4i1.8870 URL: http://dx.doi.org/10.5296/ijssr.v4i1.8870

\begin{abstract}
This paper aims to identify the nature of the relationship between democracy and economic growth. We will answer the question: Does democracy improve economic growth? We study the case of Tunisia during the period from 1980 until 2014; this country has experienced a democratic transition after the revolution of $14^{\text {th }}$ January 2011. Our study is divided into two parts. The first part is a literature review of overview on the causality between democracy and economic growth. The second part as an application uses the Autoregressive Distributed Lag Model (ARDL). The choice of the technical SARL aimed the study of the existence of a long-run equilibrium relationship between two variables in level, a procedure co-integration
\end{abstract}


has been proposed by Pesaran et al (2001). The results of different empirical studies were inconclusive. Some generated a negative impact of democracy on growth while others showed the opposite. The empirical results of our work have shown that in a nascent democracy such is the case of Tunisia; democracy has no effect on economic growth in the short term. It is to add an observation rate of GDP during the period post -revolution generated a sawtooth trend which demonstrates the unstable economic situation in the country.

Keywords: Democracy, Economic Growth, stationary, ARDL, co-integration

JEL Classification: D72, O43

\section{Introduction}

The debate on the nature of the relationship between democracy and economic growth has taken several directions. Economists disagree on the direction of causality between these two concepts. Is democracy a factor or rather a brake to economic growth? This controversy has been expanded with a focus on whether or not the establishment of a democratic regime. Given the ambiguity of economic performance and the gap experienced by those who are interested in the relationship between these two concepts, we tried to open this debate and to clarify this relationship.

Thus, in this article, we will address this debate in the first part theoretically and empirically studied through the experience of Tunisia in the second part.

\subsection{Democracy and Economic Growth: Review of Literature}

Democracy has always been seen as a solution for stable growth in the long term. Thus, according to Brunetti (1997) two essential features characterize the relationship Study of democracy and growth: the abundance of work and heterogeneity of results against a multiplicity of theoretical theses issued. Indeed, several studies confirm the positive impact of democracy on the process of economic growth, while others have reported a negative effect. Another wave finds no effect. The controversy between democracy motor and / or brake to economic growth was reached by the ambiguity of the debate from several authors such as Helliwel (1994), Prezworski and Limongi (1993) who reported that there is no net systematic effects of democracy on growth.

\subsubsection{The Positive Impact of Democracy on Economic Growth}

For the first wave of ideas democracy has a stabilizing role on the economic growth. Within this framework of ideas, Özler and D.Rodrik (1992) find that civil and economic freedoms have a positive effect on growth because they reflect less state involvement in the country's economic activity.

In addition, the study by D. Rodrik (1997), from the comparison between authoritarian and democratic regimes, found that it is best to achieve economic prosperity. It identified four fundamental results: the Democracy allows the realization of a long-term growth rates, 
guarantees economic stability, reacts quickly in case of the existence of global changes and ensures high salaries.

He shared with A. Sen (1991) the idea that decentralized political systems particularly the democratic system, can be volatile. His empirical analysis has shown that the transition from autocracy to democracy is accompanied by a small decrease in the GDP growth rate of $1.3 \%$, the consumption $2.3 \%$ and investment by $4.4 \%$. Regarding the last result, he found that there is a strong relationship between the extension of democratic rights and the wages received by workers.

For his part, Kurzman (2002) studied 106 countries over a period from 1951 to 1980 . He found that a democratic regime slightly stimulates growth through investment and public spending.

In another recent study, Daron Acemoglu, Suresh Naidu, Pascual Restrepo and James Robinson (2014) offer their own assessment of the impact of democracy on GDP by observing a group of countries between 1960 and 2010. They show that the democracy stimulates economic growth. Indeed, the democratization increases per capita GDP of about $20 \%$ over the next three decades.

Through a sample grouping 129 countries, Pak Hung Mo (2000) show the effect of political rights on real GDP growth rate per capita. In his study, he used several transmission channels that highlight the link between economic growth and political rights. The model data used refer to the period from 1970 to 1985.

He tried to show what level of political rights permits to promote economic growth. It reached an optimal level of political rights which promote economic growth. This level varies when different transmission variables are included in the regressions; this proves that this level varies according to the specific characteristics of each country.

The same authors also find that a country is more likely to adopt a democratic system than its neighbors have themselves experienced a democratization in previous years; conversely, one country is more likely to adopt an undemocratic regime that its neighbors have switched to such a scheme in previous years. Thus, democratization tend to occur in regional waves. According to the authors, democracy stimulates economic growth by encouraging investment, increasing education (especially in primary education), pushing the government to implement economic reforms, improving the provision of public goods, including stimulating public services in the health field, and finally by reducing social disorder. In particular, they find that the positive impact of democracy is particularly important that economies have a large share of the population in secondary education. It seems all the more to stimulate economic growth that the country initially has a high level of education. 


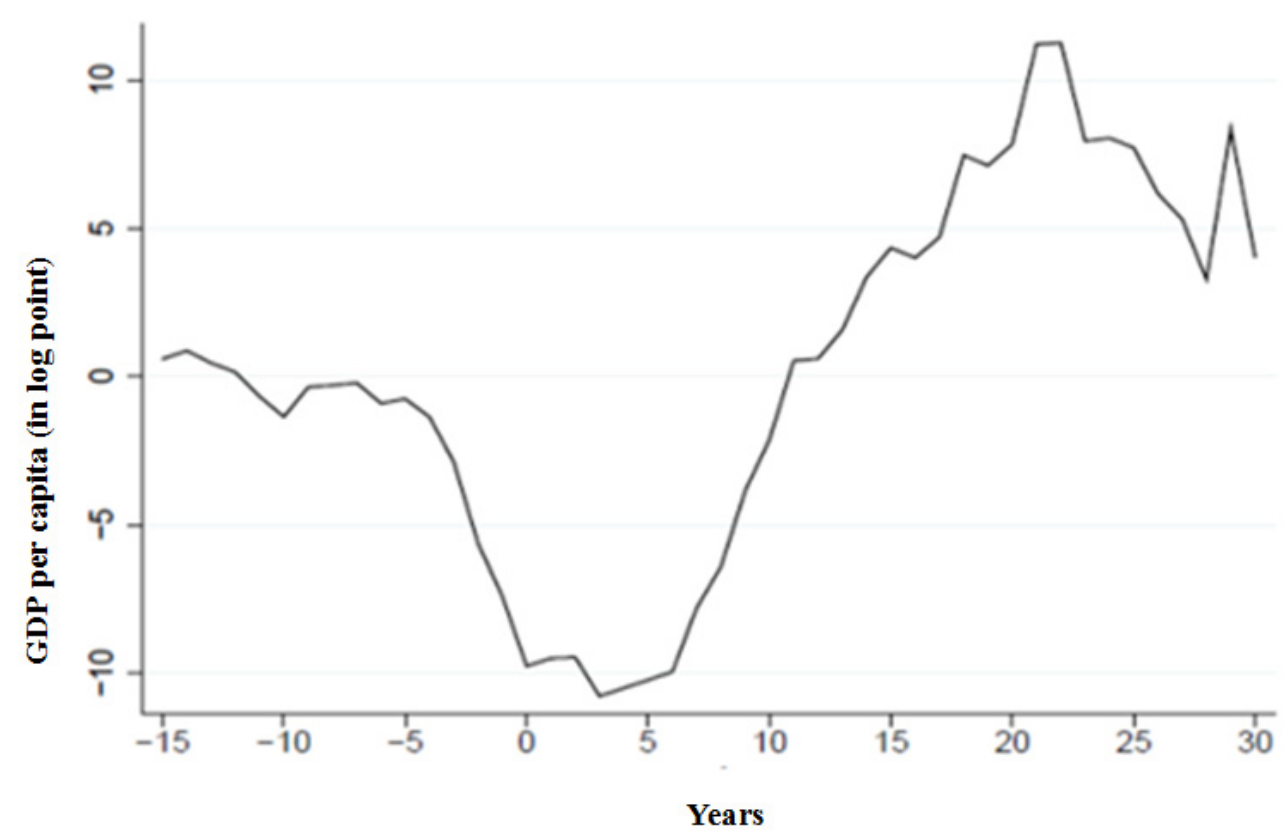

Source: Acemoglu et al (2014)

Figure 1. GDP per capita around Democratization

The graph shows the per capita GDP (in logs) of countries adopting democratic rule over those who have not abandoned their authoritarian regime.

Another more recent study by Klaus Grundler and Tommy Krieger (2015) using a new measure of democracy (SVMDI) based on the index of Support Vector Machines. They show that democratic countries have more educated populations, greater investment shares, lower fertility rates but not necessarily higher levels of redistribution. They find a nonlinear relationship between the two.

Another variation of ideas is a close relationship between the quality of institutions and economic growth. Within this framework of ideas, H. Edison (2003) note that the institutions are defined "in reference to the protection of property rights, the equitable application of laws and regulations and corruption". According to the study by Edison, institutions have a statistically significant effect on economic performance. They substantially increase per capita GDP no matter the quality of institutions is measured by global indicators (such as an indicator associate perceptions of public sector management) or specific indicators (such as the degree of protection of property rights and enforcement of the rule of law). Edison concludes that developing countries can improve their economic performance by strengthening their institutions. He found that if the average quality of institutions in sub-Saharan Africa overtook that of developing Asia, per capita income in the region would amount of $80 \%$ from about $\$ 800$ to over $\$ 1,400$.

D. Rodrik and A. Subramanian (2003) show that the quality of institutions measured by a composite indicator of several elements that capture the protection of property rights and the 
strength of the rule of law is the only positive and significant determinant income.

In the same route of ideas, Rock (2009) shows that the growth of democracy depended on the relationship between the level of development of institutions and policies implemented in the countries of Asia.

\subsubsection{The Negative Impact of Democracy on Economic Growth}

The second wave of ideas for its part, finds a negative impact of democracy on growth. Within this framework of ideas, R. Barro (1996) found that democracy has a slight negative effect on growth by observing 100 countries between 1960 and 1990. His analysis suggests the presence of a nonlinear relationship (a form related inverted $U$ ) democracy stimulates the growth of low levels of policy freedom, but tends to reduce against when a certain level of freedom is achieved. In other words, considering political freedom as luxury good, so rich countries will consume more democracy, even if it has an adverse effect on growth, because these countries have the economic ability to record a rate growth reduced by the effect of democracy.

The improvement of living standards, whether measured by the increase in GDP, life expectancy and education, increases the likelihood that a country adopts a democratic regime.

Wacziarg and Tavares (2001) use a system of equations of 65 developed countries, developing and emerging countries between 1970 and 1989. They find that democracy hinders growth by reducing the rate of physical capital accumulation and by raising the ratio of government consumption to GDP. So ultimately, the authors found a negative impact of democracy on growth.

You (2011) shows that democracy increases the level of corruption and therefore negatively affects economic growth. In the same vein of ideas, Narayan et al (2011) show that more democracy has a negative effect on real income.

For their part, Aisen and Veiga (2013) study empirically the effects of political instability on economic growth in a dynamic panel of 169 countries over the period from 1964 to 2004. They find that high levels of political instability are associated with low growth rate of GDP per head.

Political instability adversely affects growth by lowering productivity growth rate and to a lesser degree the accumulation of physical and human capital.

Alesina and Perotti (1994), unlike other studies do manage to enter any influence of democracy on growth. Democracy has no effect on growth. Several other economists found that the democratic system can in many cases play an opposite role while being detrimental to economic growth this is the case for Erich Weede (1983); Landau (1986); Adelman and Morris (1967); Huntington and Domingues (1975); Jean Paul Azam J Claude Barthélemy and Stéphane Calipel (1996) and March (1973) etc.

According to these economists, authoritarian regimes can in many cases, play a key role in boosting economic growth. Such is the case for the countries of Southeast Asia, the Latin 
American dictatorships such as Chile which achieved economic miracle due to the realized economic growth.

\section{Data}

This study employs annual time series data on economic growth and democracy index for Tunisia which cover 1980-2014 periods. The data has been obtained from different sources, including Freedom House and World Development Indicators 2014 edition published online by the World Bank.

The variable of economic growth, measured by the rate of real GDP per capita is noted by GDP and the level of democracy is measured by the average of two variables, political rights $(\mathrm{PR})$ and civil liberties (CL) is noted by democracy. These two variables vary between 1 and 7. The average ratings (PR) and (CL) determine whether the country is free, partly free or not free.

It should be noted:

- Political rights are the rights that arise in the organization of free elections and the contribution of all people without racial discrimination or religious and existence of opposition parties to promote political pluralism ...

- Civil liberties include freedom of everyone to choose his religion, to meet and to manifest.

\subsection{The Augmented Distributed lag (ARDL) Approach to Co-Integration}

The most popular single equation testing for co-integration between a set of I(1) variables relied on the Engle Granger (1987) and Phillips-Ouliaris (1990) residual based tests. Also Hansen's instability test (1995), Park's added variables test (1992) and the stochastic common trends approach of stock and Watson (1988) are well known system co- integration testing is mostly based on Johansen's $(1991,1995)$ system based reduced rank approach.

This study utilizes the autoregressive distributed lag (ARDL) approch Pesaran and Shin (1995, 1998); Pesaran et al. (1996), Pesaran et al. (2001). Recently the studies have indicated that the ARDL approach to co-integration is preferable to conventional approaches such as Engle and Granger (1987) Johansen (1988), Johansen and Juselus (1990) and Gregory and Hansen (1996).

Also the Autoregressive Distributed Lag (ARDL) test is found in applied empirical papers. The test is based on Pesarana, and Shin (1999). This technique is reported to offer several advantages. The test is based on a single ARDL equation, rather than on a VAR as in Johansen, thus reducing the number of parameters to be estimated. Unlike, the Johansen approach the restrictions on the number of Lags can be applied to each variable separately. The ARDL approach also does not require pre testing for the order of integration (0 or 1) of the variables used in the model.

In comparison with other previsions and traditional integration methods, the ARDL technique does not need that all the variables under study must be integrated of order 1 , order 0 or 
fractionally integrated, it is also relatively more efficient in the case of small and finite sample data sizes. Finally, by applying the ARDL technique we obtain unbiased estimates of the long -run model (Harris \& Sollis, 2003).

The ARDL bounds test is based on the assumption that the variables are I (0) or I (1). So, before applying this test, we determine the order of integration of all variables using the unit root tests. The objective is to ensure that the variables are not I (2) so as to avoid surious results. In the presence of variables integrated of order two, we cannot interpret the values of F- statistics provided by Pesaran et al. (2001).

The existence of an error-correction term among a number of co-integrated variables implies that changes in the dependent variable are a function of both the level of disequilibrium in the co-integration relationship (represented by the ECM) and the changes in other explanatory variables. This shows that any deviation from the long-run equilibrium will feed back on the changes in the dependent variable in order to force the movement towards the long-run equilibrium (Masih \& Masih, 2002).

The ARDL approach involves two steps for estimating the long-run relationship (Pesaran et al., 2001). The first step is to examine the existence of long- run relationship among all variables in the equations under estimation. The second step is to estimate the long-run and the short- run coefficients of the same equation. We run the second step only if we find a long-run relationship in the first step (Narayan et al., 2004).

This study uses a more general formula of ECM with intercept (Pesaran et al., 2001). We use The ARDL approach proposed by Pesaran et al. (2001) to estimate the following equation: ARDL model is estimated to examine the long run relationship:

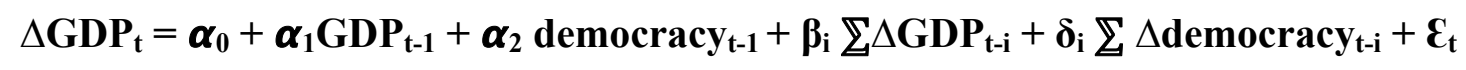

$\Delta:$ is the first difference

$\boldsymbol{\varepsilon}_{\mathrm{t}:}$ are the error terms.

If The F-statistics lies above the upper level of the bounds, the null is rejected, indicating cointegration. If the calculated F-statistics is below the upper level, we cannot reject the null hypothesis of no cointegration. Finally, if it lies between the bounds, a conclusive inference cannot be made without knowing the order of integration of the underlying regressors.

If there is an evidence of long-run relationship between variables, we can estimate the following long-run and short-run models that are represented in the following equation:

$$
\Delta G D P_{t}=\alpha_{0}+\beta_{i} \sum \Delta G D P_{t-i}+\delta_{i} \sum \Delta \text { democracy }_{t-i}+\mu_{1} \operatorname{ECT}_{t-1}+e_{t}
$$

$\boldsymbol{\mu}_{\boldsymbol{1}}$ is the coefficient of error correction term (hereafter ECT). It shows how quickly variables converge to equilibrium and it should have a statistically significant coefficient with a negative sign. 


\section{Interpretation of the Results}

\subsection{Unit roots Tests}

In time series analysis, before running the causality test the variables must be tested for stationarity. For this purpose, in this current study we use the conventional ADF tests.

Initially, we opted for ADF test to check the datasets and we observed that the datasets were non-stationary at level. However, in first difference, we found the serie become stationary (Table 1). So it became possible for us to investigate the existence of a long-run relationship within a Johansen co-integration testing framework.

Table 1. Augmented Dickey-Fuller Unit Root Test

\begin{tabular}{ccccc}
\hline \multirow{2}{*}{ Variables } & \multicolumn{2}{c}{ Level } & \multicolumn{2}{c}{ First Difference } \\
\cline { 2 - 5 } & \multicolumn{2}{c}{ t-statistic } & t-statistic \\
\hline Intercept & Trend and Intercept & Intercept & Trend and Intercept \\
\hline Democracy & -6.820886 & -6.715377 & -10.54297 & -4.234205 \\
& -0.176503 & -0.431029 & -4.661803 & -4.979758 \\
\hline
\end{tabular}

The results of the stationarity tests show that all variables are non-stationary at level. These results are given in Table 1. The ADF tests applied to the first difference of the data series reject the null hypothesis of non stationarity for all the variables used in this study. It is, therefore, worth concluding that all the variables are integrated of order 1 .

\section{2-ARDL bounds Tests for co-integration}

The ARDL model requires a priori knowledge or estimation of the orders of the lags.

We begin with the determination of the appropriate length of $p$. The table 2 reports the Information Criteria for all lags up to three (for $p=1,2,3$ ) over the period 1980 -2014. According to the Information Criteria for all lags we find a lag $=1$.

We have using the Wald test to compute the long run relationship between economic growth and democracy.

Table 2. Results from Bound Tests

\begin{tabular}{llll}
\hline & Lags & F-stat & Decision \\
\hline Fodp $($ GDP/democracy) & 1 & 17.44074 & co-integration \\
Lower -bound critical value at 1\% & 7.41 & & \\
Upper - bound critical value at 1\% & 8.37 & & \\
\hline
\end{tabular}

Lower and Upper-bound critical values are taken from Pesaran et al. (2001). 
From these results, it is clear that there is a long run relationship among the variables when $G D P$ is the dependent variable because its F-statistic (17.44) is higher than the upper-bound critical value ( 8.37 at the $1 \%$ level). This implies that the null hypothesis of no co-integration among the variables in equation (1) is rejected.

\subsection{Granger Short Run and Long Run Causality Test}

We will study the causality between democracy and economic growth in the short and long term. The results of the ARDL model are summarized in the following table.

Table 3. Results of ARDL Approach

\begin{tabular}{cccc}
\hline Variable & Coefficient & t- statistic & Prob. \\
\hline C & 4.138691 & 1.454532 & 0.1569 \\
GDP (-1) & -1.567511 & -5.569195 & 0.0000 \\
DEMOCRACY (-1) & 0.461447 & 0.752038 & 0.4583 \\
D (GDP (-1)) & 0.170319 & 0.989538 & 0.3309 \\
D (DEMOCRACY (-1)) & 2.033664 & 2.472421 & 0.0198 \\
R-squared & & 0.71 & \\
F-statistic & & 17.15 & \\
D.W & & 1.95 & \\
\hline
\end{tabular}

The next step of ARDL process holds the long run ARDL equation as follows:

$$
G D P=\alpha_{0}+\alpha_{1} \sum G D P_{t-i}+\alpha_{2} \sum \text { democracy }_{t-i}+\varepsilon_{t}
$$

The relationship between GDP and Democracy as be written:

$$
\text { GDP }=0.795 * \text { Democracy }
$$

The coefficient can be interpreted as elasticity. A $1 \%$ increase in democracy results in an $80 \%$ increase in output.

The error correction term ECT can be written:

$$
\mathrm{ECT}=\mathrm{GDP}-(\mathbf{1 . 0 6 7 0 1 9} /-1.341776) \text { democracy }
$$

The coefficient on the lagged error-correction term is significant at $1 \%$ level with the expected sign (Table 4), which confirms the result of the bounds test for co-integration. Its value is estimated to -1.59 which implies that the speed of adjustment to equilibrium after a shock is high. Approximately $159 \%$ of disequilibria from the previous year's shock converge back to the long-run equilibrium in the current year. 
Table 4. Equilibrium Correction of the ARDL

\begin{tabular}{cccc}
\hline Variable & Coefficient & t-statistic & Prob. \\
\hline C & -0.146722 & -0.380833 & 0.7061 \\
D (GDP (-1)) & 0.195293 & 1.105521 & 0.2780 \\
D (DEMOCRACY (-1)) & 1.347569 & 1.836462 & 0.0766 \\
ECT (-1) & -1.592437 & -5.499420 & 0.0000 \\
R-squared & & 0.681431 & \\
F-statistic & & 20.67732 & \\
D.W & & 1.870759 & \\
\hline
\end{tabular}

Now we want to estimate the short run causality. We use Wald statistics test which shows short run causality result between democracy and GDP. Result show that there is no short run causality from democracy to GDP since $\mathrm{p}$. value is more than $5 \%$.

\subsection{Results of Diagnostic Tests}

Now we want to examine whether our model where GDP is the dependent variable has any statistical error or not. Here our value of $\mathrm{R}^{2}$ is $70 \%$ which is high. Our F statistic is also significant which is a good sign of our model. Breusch-Godfrey's LM Test indicates that there is no serial-correlation in our model. Further Breusch-Pagan-Godfrey's Heteroscedasticity Test indicates that this model does not have Heteroscedasticity.

Table 5. Results of diagnostic Tests

\begin{tabular}{lc}
\hline & Probability \\
\hline Breusch -Godfrey Serial Correlation LM Test & 0.5864 \\
Heteroscedasticity Test: Breusch- Pagan -Godfrey & 0.9765 \\
Jarque -Bera Test & 0.149 \\
\hline
\end{tabular}

Moreover residuals of this model are normally distributed that is desirable. The probability of Jarque Bera Test indicates that residuals of this model are normally distributed.

The Figures 2 indicate the absence of any instability of the coefficients because the plot of the CUSUM statistic falls inside the critical bands of the 5\% confidence interval of parameter stability. 


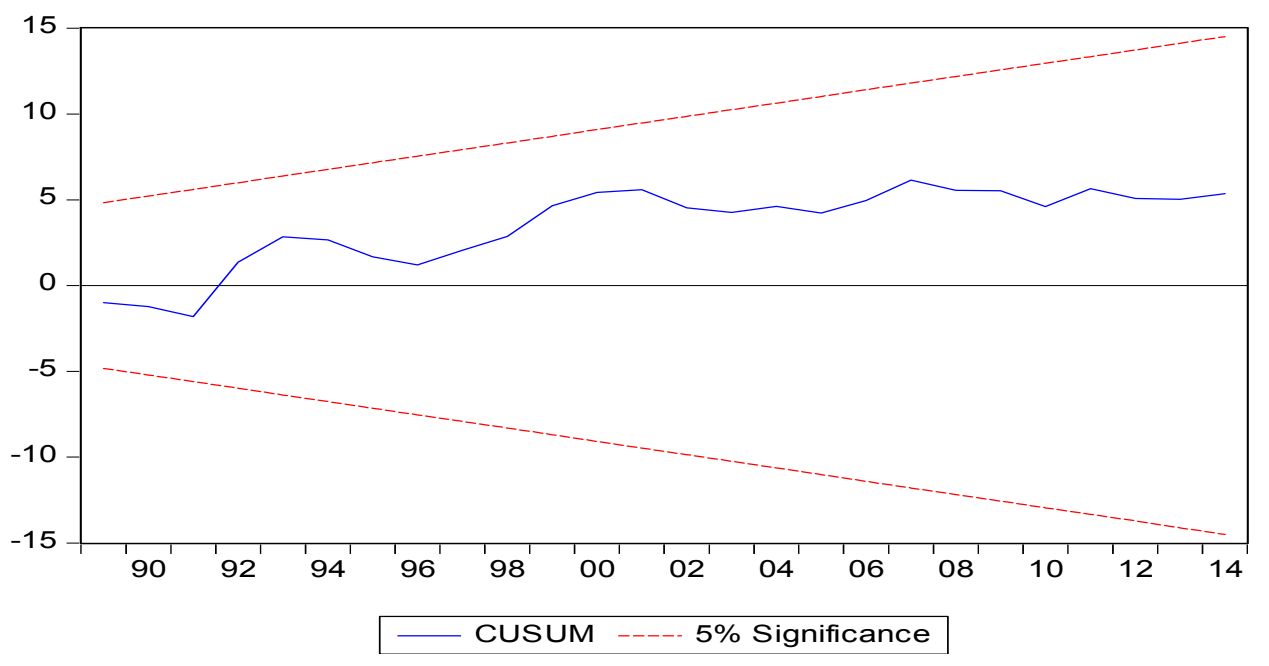

Figure 2. Plots of CUSUM Statistics for Tunisia

Table 6. Statistic output for stability tests

\begin{tabular}{lccccc}
\hline & $\begin{array}{c}\text { Forecast period, } \\
\text { breakpoint }\end{array}$ & F statistic & $\begin{array}{c}\text { Probability of F } \\
\text {-statistic }\end{array}$ & $\begin{array}{c}\text { Log likelihood } \\
\text { ratio }\end{array}$ & $\begin{array}{c}\text { Probability of log } \\
\text { likelihood ratio }\end{array}$ \\
\hline $\begin{array}{l}\text { Chow Forecast } \\
\text { Test }\end{array}$ & $2011-2014$ & 0.72 & 0.58 & 3.32 & 0.50 \\
$\begin{array}{l}\text { Chow Breakpoint } \\
\text { Test }\end{array}$ & 2011 & 0.08 & 0.77 & 0.08 & 0.76 \\
\hline
\end{tabular}

The Chow break point and Chow Forecast Tests are used to examine significant break in the data in 2011 and over of the post revolution period 2011-2014.

\subsection{Policy Implications}

The negative result was due to the social protest mounted on wages and democratization process itself in Tunisia accompanied by lack of security, which affects for local and foreign investors. It is noteworthy that the political system of China is not democratic but the country annually recorded fairly high growth rate.

According to the data of the World Bank (2014) (Note 1) Tunisia's growth performance from 1990 to 2010 was good compared to its regional peers. In fact, The real growth rate of GDP per capita grew at about 3.4 percent per year during 1990 and 2010. So it was the second fastest growing country in the MENA region since 1990. The Real growth rate of GDP per capita was 3.6 in 2005, pass to 3.3 in 2008 and diminish to 3 in 2010. The revolution unfolded in late 2010, and the real growth rate of GDP per capita declined in 2011 to -1.7. In this year, the country experienced a sharp deterioration in economic growth and consequently a negative real growth rate / capita. This rate is explained by the sit-in, social tensions, the flight of foreign direct investment (IDE) and especially socio-economic impact of the Libyan crisis erupted in February 2011. 
But it emerges also that Tunisia has not experienced significant growth after the democratic transition except the year 2012 when government Troika(the real growth rate of GDP per capita grow to 3.7 in 2012). The net real growth rate of improvement in GDP / head is explained by the inflow of foreign direct investment and the significant mobilization of external resources. Finally, the real growth rate of GDP per capita passed from 1.5 in 2013 to 1.4 in 2014.

\section{Conclusion}

It appears from this study that democracy has a positive long-term effect. It is in this sense that Tunisia, a country of four years duration democracy has not experienced remarkable growth rates instead the transition from authoritarian to democratic regime led to a rate cut growth. It shows that the improved growth in a fledgling democracy cannot be realized in the short term.

Ultimately, Tunisia has experienced after January $14^{\text {th }}, 2011$, a significant improvement in civil liberties and political rights; it happened, according to Freedom House, a non-democratic country (not free) to a country in 2011 partially democratic in 2012 and 2013 and democratic (Free) in 2014 and 2015. But these gains have not been followed by an acceleration of economic growth seen political instability experienced by this country. It should be noted that since the revolution, this small country has experienced three presidents and six governments.

Also, economic success can only take place if the leaders policies do not attach to implant among citizens a democratic culture "Whatever the importance of democratic institutions, we cannot be content to regard them as mere tools, performing mechanical effects on development" Sen (2000, p.163).

\section{References}

Aisen, A., \& Veiga, F. J. (2013). How does political instability affect economic growth?. European Journal of Political Economy, 29, 151-167. http://dx.doi.org/10.1016/j.ejpoleco.2012.11.001

Alesina, A., \& Perotti, R. (1994). The political economy of growth: a critical survey of the recent literature. The World Bank Economic Review, 8(3), 351-371. http://dx.doi.org/10.1093/wber/8.3.351

Annual Report of the Central Bank of Tunisia. (2013). Retrieved from http://www.bct.gov.tn/

Barro, R. J. (1996). Democracy and growth. Journal of economic growth,1(1), 1-27. http://dx.doi.org/10.1007/BF00163340

Freedom House (n.d.). Retrieved from https://freedomhouse.org/report-types/freedom-world

Gründler, K., \& Krieger, T. (2015). Democracy and growth: Evidence from SVMDI indices (No. 131). Discussion Paper Series, Chair of Economic Order and Social Policy, Universität Würzburg. 
Hung, M. P. (2000). The Level of Political Rights And Economic Growth. Effect and Transmissions Channels. BRC Working papers, November.

Knutsen, C. H. (2010). Investigating the Lee thesis: how bad is democracy for Asian economies?. European Political Science Review, 2(03), 451-473. http://dx.doi.org/10.1017/S1755773910000214

Knutsen, C. H. (2011). Which democracies prosper? Electoral rules, form of government and economic growth. Electoral Studies, 30(1), 83-90. http://dx.doi.org/10.1016/j.electstud.2010.09.006

Knutsen, C. H. (2013). Democracy, state capacity, and economic growth.World Development, 43, 1-18. http://dx.doi.org/10.1016/j.worlddev.2012.10.014

Kurzman, C., Werum, R., \& Burkhart, R. E. (2002). Democracy's effect on economic growth: a pooled time-series analysis, 1951-1980. Studies in comparative international development, 37(1), 3-33. http://dx.doi.org/10.1007/BF02686336

Masaki, T., \& Van de Walle, N. (2014). The impact of democracy on economic growth in sub-Saharan Africa, 1982-2012 (No. 2014/057). WIDER Working Paper.

Masih, A. M. M., \& Masih, R. (2002). Propagative causal price transmission among international stock markets: evidence from the pre-and postglobalization period. Global Finance Journal, 13(1), 63-91. http://dx.doi.org/10.1016/S1044-0283(02)00039-X

Narayan, P. K., Narayan, S., \& Smyth, R. (2011). Does democracy facilitate economic growth or does economic growth facilitate democracy? An empirical study of Sub-Saharan Africa. Economic Modelling, 28(3), 900-910. http://dx.doi.org/10.1016/j.econmod.2010.11.004

Özler, Ş., \& Rodrik, D. (1992). External shocks, politics and private investment: Some theory and empirical evidence. Journal of Development Economics, 39(1), 141-162. http://dx.doi.org/10.1016/0304-3878(92)90060-M

Pesaran, M. H., Shin, Y., \& Smith, R. J. (2001). Bounds testing approaches to the analysis of level relationships. Journal of applied econometrics, 16(3), 289-326. http://dx.doi.org/10.1002/jae.616

Rock, M. T. (2009). Has democracy slowed growth in Asia?. World Development, 37(5), 941-952. http://dx.doi.org/10.1016/j.worlddev.2008.09.002

Rodrik, D. (1997). Democracy and Economic Performance. Harvard University.

Sen, A. (2000). Un nouveau modèle économique: développement, justice, liberté. Odile jacob.

Tavares, J., \& Wacziarg, R. (2001). How democracy affects growth.European Economic Review, 45(8), 1341-1378. http://dx.doi.org/10.1016/S0014-2921(00)00093-3

You, J. S. (2011). Democracy, Inequality, and Corruption: Korea, Taiwan and the Philippines Compared. In APSA 2011 Annual Meeting Paper. 
Notes

Note 1. World bank (2014):"The Unfinished Revolution Bringing Opportunity, Good Jobs And Greater Wealth To All Tunisians" Report No. 86179-TN, p36.

\section{Copyright Disclaimer}

Copyright for this article is retained by the author(s), with first publication rights granted to the journal.

This is an open-access article distributed under the terms and conditions of the Creative Commons Attribution license (http://creativecommons.org/licenses/by/3.0/). 